\title{
UKRAINE BETWEEN PEACE AND WAR WITH RUSSIA
}

\author{
Ilie-Răsvan DUMITRU, PhD Candidate*
}

\begin{abstract}
After the Crimean Peninsula was invaded and the amplification of conflicts in South-Eastern Ukraine, it has become obvious that Russia's policy is concentrated on preserving its influence and strategic control over the decisions and political directions taken by the States from the former Soviet bloc. To understand the consequences of the Russian-Ukrainian war on the West, as well as to anticipate and counteract a possible future evolution of similar events not only in geopolitical risk states such as Moldavia, but also even in NATO members such as the Baltic countries, Romania or Bulgaria, it is worth paying attention to the geopolitical consequences of the loss of Crimea and the South-Eastern provinces by Ukraine. The article analyses the reason, mechanisms and stakes behind the Russian-Ukrainian war, from both a geopolitical and historical perspective. To understand the way in which different hybrid instruments can be used by the Russian Federation to influence the States in its proximity and, in particular, how their combination leads to effective satisfaction of the aims, it is useful to assess and address the systemic risks and vulnerabilities of States in the concerned areas of Russia and the West in recent years.
\end{abstract}

Keywords: Ukraine; Russian Federation; Crimea; Russian-Ukrainian war; hybrid warfare; limited warfare; maskirovka.

Ukraine is a sovereign state in the Eastern Europe, the second largest on the continent, after Russia, with an area of $603,634 \mathrm{~km}^{2}$. The capital city of Kiev is located on the Dnieper River, in the North-Central of Ukraine. It is bounded by Belarus to the North, Russia to the East, the Azov Sea and the Black Sea to the South, Moldavia and Romania to the South-West and Hungary, Slovakia and Poland to the West. The Kerch Strait, connecting the Azov Sea with the Black Sea, separates Ukraine from Russia in the South-East region.

Ukraine's history is a complex one, its origin starting from the establishment in the 9th century of the first Eastern Slavic state called Kievan Rus'. In the 10th and 11th centuries, it became the largest and strongest state in Europe. Since the 11th century, weakened by many internal conflicts and the invasions of Mongols tribes, Kievan Rus' has been incorporated into the Grand Duchy of Lithuania and later into the Polish-Lithuanian State union. In the middle of the 17th century, following internal riots against Poles, a new Ukrainian state called the Cossack Hetmanate emerged, and managed to remain autonomous for more than 100

\footnotetext{
*"Carol I" National Defence University

e-mail:dumitrurasvan@yahoo.com
}

years. Since the end of the 18th century, most of the ethnic Ukrainian territory has been embedded in the Russian empire, the western regions of this territory (Galicia and Transcarpathya) being absorbed by the Austro-Hungarian Empire.

The fall of the Tsarist Empire (1917) allowed Ukraine's independence from 1917 to 1920 . During 1921-1991, Ukraine was a republic of the Soviet Union. Thus, a completely independent Ukraine was only born at the end of the 20th century, after long periods of successive domination of the Polish-Lithuanian kingdom, Poland, Lithuania, Grand Duchy of Moscow, Russia and the USSR. At the collapse of USSR in 1990-1991, the Ukrainian SSR legislature declared sovereignty (July 16, 1990) and then absolute independence (August 24, 1991). The independence was confirmed by popular approval in a plebiscite on December 1, 1991, with the dissolution of the USSR.

Ukraine's short history points out that the current Ukrainian territory has been occupied by various countries over the centuries, the borders being changed several times. Some regions that are currently part of Ukraine belonged in the past to other countries such as Austria, Poland, Moldavia or Russia. The modern territory of Ukraine hosts a variety of ethnic groups (Ukrainians, German, Polish, Russian, Ruthenic, Tatars or other ethnic group) and religious (Catholics, Greek Catholics, 
Lutherans, Russian orthodox, Jews, Muslims or other confessions). During the peak of the USSR, an intensive policy of forced migration of the population was pursued, the ethnic Ukrainians dropping from $77 \%$ in 1959 to $73 \%$ in 1991 . This trend of ethnic depopulation reversed after Ukraine regained independence, reaching at the beginning of the 21 st century to account for more than threequarters of the country's population. The Russians continue to be the largest minority, although they currently occupy less than a fifth of the population. The rest of the population includes: Belarusians, Moldavians, Bulgarians, Poles, Hungarians, Romanians, Roma (gypsies) and other groups. The ethnic group represented by the Crimean Tartars, who were deported by force to Uzbekistan and other Central Asian republics in 1944, began to return in large numbers to Crimea after 1989; at the beginning of the 21st century, they were one of the largest minority groups that were not Russian.

Ukraine's importance for the West increased with the importance granted by Russia to this state. The inability of the West to comprehend the significant role of Ukraine in tempering the expansionist policy of Russia created the grounds of the Russian-Ukrainian conflict emergence. This is not the case for Kremlin too, the Russian decision-makers considering that the Eurasian Union is not complete without Ukraine ${ }^{1}$. Thus, the Russian policy, especially after 2000 , turned to the reconversion of Ukrainian geopolitical status by reconsidering it as a buffer zone between the West and the Russian Federation, in its membership of the Eurasian space. As the annexation of Crimea to the Russian Federation, through its abusive occupation in 2014, caused a surprise to the Western governments, it reflected either a poor understanding of the nostalgic Russian spirit of the historical greatness under the leadership of Peter the Great, of Catherine the 2nd or Alexander the 1 st, or an unacceptable underestimation of Russian ability to reinvent and revive the warrior spirit of the old Cossacks.

An area of strategic interest, both for the Russian Federation and for the West, is the Crimean Peninsula; a land of $27,000 \mathrm{~km}^{2}$, extending into the Black Sea, which has been the gateway for the Greeks, Romanians, Byzantine, Mongols and Turks, to the northern Black Sea lands and to the vast fertile land of the North European plain.
Located on the northern shore of the Black Sea and on the western coast of the Azov Sea, Crimea is almost an island being connected to the continent only by a strip of land of about $5-7 \mathrm{~km}$ wide represented by the Isthmus of Perekop. A large part of the natural boundary separating the continental region of Ukraine (Herson) from the Crimean Peninsula is characterized by a geographical set of interrelated lakes and lagoons on the west coast of the Azov Sea.

In addition to the continental link through the Isthmus of Perekop, Crimea is linked to the Hencesk district of the Herson region through bridges crossing the Chohar and Henicesk Straits. The eastern end of the peninsula, represented by Krasnodar region, is made through Kerci Strait, connecting the Black Sea with the Azov Sea, being 3-13 km wide.

With little human and economic potential, only $1,967,200$ inhabitants in 2014 , the peninsula does not have the political force to play a geopolitical role on its own, but, together with a great power, it becomes of great geostrategic importance for all the surrounding regions. This was also the reason for the historical dispute, among the great powers, Crimea being regularly taken over by successive administrators (Greek, Romanian, Byzantine, Mongols, Turkish or Russian) through bloody wars. Like in the past, today's Crimea is a region torn apart by the interests and geopolitical competition between the current great powers, the European Union, Russia, the US and China.

From a geostrategic point of view, I believe that Ukraine is the natural hinterland of the Crimean Peninsula; therefore, through its geographical position, as a country that includes the northern shores of the Black Sea, Ukraine is predestined to rule over this region. But history shows us that the geostrategic interests of the great powers have determined that several times strategic important territories were disconnected from their geographical connections, entering under the influence of neighboring powers (Transnistria, South Ossetia, Abkhazia, and so on) or colonial empires (Gibraltar, Singapore, the Panama Canal, Gdansk, and so on).

To understand why some strategically positioned territories have presented great interest for the major powers, we have to analyze the very essence of the theory of geopolitical pivots. For one 
of the founders of the Ukrainian ${ }^{2}$ geopolitical forces, which has faced the extremely important problem of defining Ukraine's geographical borders, its geopolitical importance lies in its expansion into the Black Sea, in close proximity to the Middle East. This geographical reality makes it into a real bridge between the West and the East. The importance of this region is not recent, as it has been discovered since the Hellenistic period, the Greeks being the first to establish commercial ports located on the northern Black Sea coast. The Romanians continued the Greek trade policy, followed by Byzantine and Italian republics. In fact, the Venetian commercial empire has been strengthened at the expense of trade in the Mediterranean and the Black Sea, bringing an important contribution to the development of regions located at north of the Black Sea. The region's geostrategic potential has generated misunderstandings between the Ottoman and the Tsarist empire, intensely disputing their supremacy over Crimea. From the end of the 16th century to the 20th century, no less than 12 Russian-Turkish ${ }^{3}$ wars were held, each side seeking to increase the political and economic influence on the peninsula.

At the beginning of the 20th century, Ukraine was seen as a communication hub to which all the shipping routes between Asia and Europe converge. Ukraine's geographical position on the northern Black Sea coast, linked it to Russia's expansion route to the Balkans and the entry area of European influences to the Caucasus, Iran and Turkmenistan. Thus, an independent Ukraine protected a number of nations in Eastern Europe and neighboring areas of Asia from Russian imperialist expansion and became a strategic stabilizing factor. Rudnicki concluded that the main direction to be followed by the future state, in order to build independent Ukrainian statehood, had to be on the Black Sea direction, on a north-south axis, which was meant to unite two different cultural elements: Cossacks and Galicians ${ }^{4}$. According to him, positioning on this vertical axis was a constructive Ukrainian response to the Russian policy of treating the Ukrainian area as a buffer zone for the Eurasian region and as an area of own influence and expansion for the German policy aiming at the Middle East. The focus on this vector was a Ukrainian geopolitical strategy to prevent its division into Eastern and Western power areas.
The opinion of the Anglo-Saxon geopolitical school, through its representative and founder ${ }^{5}$, supported the Heartland theory, whereby the geographical region of Ukraine is considered one of the most important territories in the world. In his view, the geostrategic importance of the world is given by the interior of Eurasia, considered the hub of Heartland, of which Ukraine is also part. Mackinder claimed that inner Asia and eastern Europe (the heart) had become the strategic center of the "World's Island" as a result of the relative decline of maritime power against land power and the economic and industrial development in Southern Siberia ${ }^{6}$. Mackinder did not give a precise definition to Ukrainian territory, but he identified this region of Eastern Europe as a fertile ground for expanding the world powers over which AngloSaxons should have thought, in order to be able to preserve a balance between the powers fighting for the control of Heartland.

In the 1900s, when the Heartland theory was released, the World's Island population represented almost $90 \%$ of the world's population ${ }^{7}$. The World's Island covered a large territory composed of: Europe, Asia and Africa, which also had similar proportions in the world economy. It included demographic, commercial and colonial empires such as: England, France, Russia, Austria-Hungary, Japan, China, Spain, Portugal, Germany, the Ottoman Empire or Italy. According to Mackinder's theory: "Who rules Eastern Europe commands Heartland; Who rules Heartland commands the World's Island; Who rules the World's Island commands the World"8. Based on his observations, Mackinder concluded that the majority of the world's population lived in the Eurasian and African land region and the control over this "world's island" would lead to a possible global dominance. This island could be best controlled from the pivot (heart) area, which would guarantee food self-sufficiency for the country that dominates the region, and the protection of the permeability of the pivot area at sea by controlling access to the Black Sea would provide a formable defensive barrier ${ }^{9}$. The pivot area was only vulnerable to ground attacks through the plains in Eastern Europe, which points out that this region included a part of Ukraine, particularly the Crimean Peninsula.

Another successor of the Anglo-Saxon geopolitical school is Z. Brzeziński, one of the most 
important theorists of contemporary globalism. Creator of geopolitical pivots' theory, he pays particular attention to Ukraine, reconsidering the importance of this state through its important geographical location and the effects of potential political instability on geostrategic behavior. As a geopolitical hub, Ukraine can allow access to strategic areas or can provide a defensive shield for an important actor or even a region. For this reason, an important aspect of America's global geostrategy, whose interests are represented by Z. Brzeziński, is the identification and protection of the States (including Ukraine) that play the role of geopolitical pivots. "Ukraine, - an important new area on the Eurasian chess table, is a geopolitical hub, because the very existence of an independent Ukrainian state is helping to transform Russia. Without Ukraine, Russia ceases to be a Eurasian empire: it may still try to achieve imperial status, but it would then be a predominantly Asian empire, constantly drawn into ruined conflicts with the recently sovereign nations of Central Asia, that would not reach an agreement on the loss of independence and would be supported by colleagues from Islamic countries in the south. [...] If Moscow, however, regains power over Ukraine, along with fifty-two million citizens, huge natural resources and access to the Black Sea, it will automatically regain the possibility of becoming a powerful empire that connects Europe and Asia together" ${ }^{\prime \prime}$.

In the 1920s, the German geographer Karl Haushofer used the geopolitical theory, proposed by the Swedish political analyst Rudolf Kjellen in 1905, to support Germany's invasion of neighboring States, which he regarded as an "expansion". $\mathrm{K}$. Haushofer is the creator of the term "Lebensraum", meaning the German influence and the way in which the Slavic East was organized, which was to be under the exclusive sphere of influence of Nazi Germany. The geopolitical theory was used to justify a state actor's attempts to expand on the basis of his own needs. Haushofer claimed that densely populated countries such as Germany should be allowed and should have the right to expand and acquire the territory of less populated countries.

The outline of Ukraine's ethnographic and territorial area can be found in Fryderyk Neumann's book"Mittleuropa",publishedin $1915^{11}$.Neumann's analysis argues the German influence exercised in Eastern Europe, based on the principle of socalled "productivism" theories. In the view of the German geopolitical school, Ukraine was to join the "German productive area", to become a buffer zone of Western civilization, a space for German expansion in the Middle East and hydrocarbon deposits in the Caucasus, Germany's agricultural and resource base, an agricultural and industrial region (the so-called "ancillary economy") and a cheap but qualified reservoir of workforce.

An ardent contestant of Z. Brzeziński's theory and, in particular, of the entire Anglo-Saxon geopolitical school of today is Alexander Heli Dughin $^{12}$, who also has the status of Putin's personal adviser. In its view, Ukraine is an essential state for the establishment, consolidation, imposition and expansion of the Eurasian Union. Dughin has repeatedly stressed ${ }^{13}$ that Ukraine is entering the final phase of its independent political existence. From a geopolitical point of view, he considers that Ukraine's stability and unity has been fragile from the very beginning of its existence, and is now entering the final phase of its independent political existence. Dughin believes that, in fact, Ukraine unites two nations with diametrically opposed policies. A Christian nation - the "East", which has a common destiny with the Great Orthodox Russia. The second nation - the "zapadniacki" - which lives in a past linked to the Polish state and the Austro-Hungarian monarchy, with a proWestern cultural and political orientation. $\mathrm{He}$ warns that if the two nations succeed in reaching an agreement between them, establishing a balancesharing consensus between Europe and Russia, and not joining NATO and the EU, Ukraine will be able to maintain its independence and survive as a single political body. Dughin is a supporter of the Eastern Europe Sea project, by reconsidering and reorganizing Heartland, also considering that without Ukraine, Russia appears to be insufficient both in space-strategic, demographic or political terms ${ }^{14}$. Practically all geopolitical analyses point out that Ukraine is connected to Russia, the latter being vulnerable, incomplete and without the geostrategic potential of Ukraine's territory, with a Ukraine included in Western structures. A Western Ukraine, which can also host a NATO naval base, is unacceptable to Russian politics, as it is perceived as a direct threat to the security, stability 
and integrity of the state and the entire Russian tradition.

In this geopolitical context, Russia appears to be an undeniable leader of the Eurasian integration structures representing materialized versions of the Dughin ideology. The Eurasian Community and now the Eurasian Economic Union are the means to strengthen the Russian regional leadership and imperial renaissance, considered the means to counterbalance Western influence, the main task of the Russian leadership being to ensure Ukraine's membership in such organizations.

Due to international circumstances, generated by the growing economic competition, Ukraine has found itself in the middle of geopolitical turbulence arising from the chain of competition between the great powers. In other words, it is in the middle of a competition cyclone, geopolitical gravity and civilization rupture caused by its position at the crossroads between the West and East, which gives it a status of a victim of geography. Today we see an increased competition for influence in Eurasia through the collision of two integration European paradigms (market economy, democracy, Western civilization) and Eurasian (oligarchic authoritarianism, corruption and autocratic administrative power).

Considering Moscow's policy of recovery of the Russian Sea and the fact that it sees NATO expansion to the East as a real threat to the security of the Russian state and identity, all States with a common border with Russia, having a pro-Western attitude, are condemned to be reconsidered and become buffer zones for it. In this respect, in the last years, Russia led a propaganda for the determination of Ukraine's political factors to give up the Euro project and finally opt for Russian Eurasian. Such political pessimism was reinforced in 2013 by the refusal of president of that time, Viktor Ianukovici to sign the Ukraine-EU Association Agreement, largely due to promises of economic support from the Russian Federation.

After V. Ianukovici's withdrawal as President of Ukraine, following the Euromaidan protests in the winter of 2013, Russia lost its main means of maintaining Ukraine under its geopolitical influence $^{15}$. After his flight to Russia and following the events in Ukraine, which followed the takeover of power by a pro-Western political elite, Kremlin started to implement the scenario of Crimea annexation and the Southeast region of Ukraine. In this respect, Russia has supported the separatists in these regions, which led to a more widespread amplification of the conflict. Ukraine has thus become a safe victim of the great powers' geopolitics, due to the interests and political confrontations between Russia, the EU and the US. As a result of the conflicts that have been triggered on its territory, I believe that Ukraine is trapped in the struggle of the Russian system for survival, as well as the inability of the West to protect the international legal space.

Changing Ukrainian state borders, by annexing the Crimean Peninsula, and fueling this conflict, by maintaining tensions in the southeastern Ukrainian regions hosting a major Russian and pro-Russian community, was a challenge by which Russia has shaken the Western world and the global order in general. The conflict in Ukraine opened a new page of Russian foreign policy, its international relations and the formation of security strategy. Russia's reaction was forced by the transformation of the political regime in Ukraine, which was taken as a challenge to its status and a geopolitical threat from the United States.

According to most Western and local military analysts, Russia, taking advantage of the uncertainty and lack of Western reaction, is trying to "freeze" the conflict, forcing the emergence of separatist regions identical to those in Georgia or the Republic of Moldavia, or to end it under favorable conditions, that would guarantee the preservation of Russian cultural identity in Southeast Ukraine by officially confirming the Russian language as the second official language of the state. These aspects will guarantee that Kiev will no longer join NATO and the EU in the future, weakening the Western rigidity that Kremlin is feeling acutely.

Despite the fact that Ukraine claims to be a geopolitical bridge between Europe and Eurasia, it primarily fulfills the role of a strategic border between the EU and Russia. Speaking about Russia's geostrategy, I believe that Ukraine is the last bastion in the way of Western democracies, for Kremlin and Russia itself. By supporting the Ukrainian conflict, Russia is trying to stop the expansion of the EU and NATO to the east, to maintain its influence in Eurasia. For Kremlin, Ukraine represent only one piece on the great geopolitical chess board, in confrontation with the USA, along with other 
playing pieces such as Syria, Iran or Venezuela, its victory in the Ukrainian war being perceived as another US defeat.

Russia's hostile actions in Ukraine have intensified the interest of military strategists in the concept of hybrid warfare. For many Western analysts, the "hybrid" concept represent the easiest way to describe the complexity and combination of tools and methods used by the Russian Federation during the annexation of Crimea, as well as support for separatist groups in eastern Ukraine. Whether it is argued or not, in the plan and with the means of any geopolitical faith, ideology or strategy, the Russian-Ukrainian hybrid warfare is the natural way of imposing power relations, by persuading Kiev to accept the Kremlin's conditions and vision for a system designed to guarantee Russia's advantages and dominance.

What stands out in the conflict in Ukraine in relation to the hybrid warfare is the focus on non-military methods and, in particular, on the information warfare, which is essential for Russia's successful campaign in Crimea in 2014. The Russian strategy included and includes a traditional combination of conventional (classic military actions) and unconventional (undercover operations) combat techniques, but also support for political protests, economic constraints, cyber operations, all complemented and supported by an intense and aggressive campaign of disinformation. At tactical level, the electronic war (EW), the psychological war and cyber sabotage, also found in the Russian-Georgian conflict in 2008, have diminished the capacity of Ukrainian authorities to respond, while wider media manipulation and exploitation techniques have diluted the boundaries between truth and lie, creating alternative realities for observers who agreed to the Russian press's position on the events.

Russia has used intensive information and propaganda operations to influence and shape public perception, exploiting existing societal vulnerabilities, undermining the perceived legitimacy of the Ukrainian state, and weakening government and state institutions. In Ukraine, Russian propaganda has adapted to exploit conservative, Orthodox and nationalist feelings, aimed at increasing the opposition to the integration with the rest of Europe, by speculating the high level of cultural conservatism, strong opposition to
LGBT categories and the integration of religious minorities. The information warfare promoted by Kremlin in the Ukrainian war, exceeds the propaganda which promotes various veridical realities, aiming by aggressive and insistent propaganda, at the creation of parallel realities that alter or influence Ukraine's foreign policy, security and defence decisions ${ }^{16}$. The alternative realities promoted in this conflict, through a subversive propaganda that perverted the objective truth, pursued and follows the distortion of the perception of a target audience.

The manipulation of the Russian, Ukrainian or pro-Russian Western collective mind shall be carried out in the visible, concerted, planned, integrated and step-by-step spectrum by achieving the following objectives:

- Direct promotion of Russia, of its leaders and its official narratives that are presented in a nationalist, patriotic, conservative, grandiose historical light, loyal to the Russian spirit and Orthodox Christian values;

- The increase of uncertainty, the amplification of dilemmas, the subtle inoculation of false truths. This is achieved by subtle propaganda that generates emotions, by activating centers of personal sensitivity. The purpose is to extract from the population a mass of maneuver that has a weakness and appetite for conspiracy theories, and practices suspicion as a rule and is highly critical to any element of internal decision or construction;

- The identification of the common enemy, through the construction of which the cohesion and the preservation of the unity of the Russian society, around the leaders is imprinted;

- Building a mood based on fears and uncertainties. This objective overcomes the preparation of moods, the conditioning of reactions and the activation of certain previously conditioned reflexes at one time;

- Construction of a human instrument that can be activated at the right time. At this stage are identified, recruited and ready for activation, the losers, supporters, contestants, useful idiots, support groups and maneuvering masses. The most important part of this component is the identification, selection, training and conditioning of persons convinced of alternative narratives, by rewriting perceptions from the individual mind. They are prepared to become conscious 
manipulators, obedient disinformers, consenters of the information warfare.

Planning the information warfare was carried out on three levels: global, regional and local. Thus, against the background of the deterioration of Russian life and the internal economic situation, Russian authorities withdrew, being able to distract both Western population as well as Ukrainian and Russian ones from social problems, relying on exploiting the nostalgic thesis of Russia's special characteristics. In this respect, the spiritual center of the Orthodox Church is promoted as a last Orthodox defence against a hostile environment represented by the depraved West ${ }^{17}$. In addition, attention is distracted from all domestic problems and tensions in Russia by promoting the obedient media and propaganda, which attempts to show that US policy is moving toward the isolation and destruction of Russian sovereignty. Thus, one of the main components of Russian policy is the creation of an enemy to help build the confidence and cohesion of the society surrounding the regime and the leader.

However, popular and political support for the escalation of the conflict in Ukraine should be seen as an attempt by the Russian elite to keep Putin's authoritarian system in the face of recession and imposed sanctions. Successful Europeanization and prosperity of Ukraine would question the effectiveness of anti-democratic regimes, extrapolating the effect on many postSoviet countries, including Russia. The fiasco of the successful transformation strategy in Ukraine would serve as a clear example of the democratic revolt of a large Orthodox country for Russian society. Therefore, Russia's limited military intervention in Ukraine is primarily aimed at preventing pro-Western reforms in Kiev. We can also assume that Russia's strategy is aimed at economic collapse, the withdrawal of popular support and the administrative collapse of Ukraine, not through large-scale open military intervention and the subversion of the state challenge, but at increasing the dissatisfaction of the population and removing the pro-Western authorities.

The use of special troops was obvious in the 2014 conflict, although their engagement is not a new strategy in Russian military thinking. Known as Spetsnaz units, these forces were once designed, in the second half of the 20th century, to carry out "special recognition" missions (acquiring information about major economic and military installations and either destroying them or taking them out of action; carrying out punitive operations against rebels, conducting propaganda; training insurgents' detachments and so on), in order to undermine the political, economic and military potential and the morale of a probable or real enemy. In Crimea, little green men were deployed to take control of public institutions, government institutions, and important infrastructure objectives. To legitimize Russian action, Spetsnaz forces facilitated and supported the arming of the separatist militia. After the surprise caused to the west by the shock of the Crimean invasion, the Russian hybrid aggression against Ukraine has slowly but surely turned into an interwar training phase. Thus, the Russian-Ukrainian conflict has become an internal war based on the civil conflict that has been triggered and fueled from the outside, in which an aggressor participates insidiously and secretly by subversive troops and local militias, as well as by "volunteer formations", groups of foreigners and mercenaries. Throughout this time, by promoting intense black propaganda, the Russian government promoted uncertainty and confusion, repeatedly denying Russia's involvement in the conflict.

Other instruments and techniques of hybrid warfare have been used to demoralize, demotivate and intimidate Ukrainian troops. They included large-scale military exercises with conventional troops on the Ukrainian border, cyber-attacks on Ukrainian government systems, electronic war that disrupted Ukrainian media stations, a diplomatic offensive and intense media to undermine the legitimacy of the new Ukrainian government. The ultimate aim of this type of "war" is to apply psychological pressure to cause the collapse of the target state from within, so that the political objectives of the conflict can be achieved without a fight - identical to the area of strategic abilities found in Sun Tzu's Art of War.

Many of the methods and tools used by Russia in the Ukrainian conflict date back to the Soviet era by the application of Maskirovka ${ }^{18}$ (disguising, camouflage, diversion or military deception). Maskirovka uses methods of actions/ intentions camouflage, denial of actions/intentions, manipulation and disinformation, which are executed during war as well as during peace. In the 
21st century, ICT progress increased the efficiency and scope of Maskirovka, allowing the Russian government to use state-scale media propaganda and disinformation ${ }^{19}$. They have been used to support the government's foreign policy in Russia and to lead a more effective "information warfare" against Ukraine and the West. The efficiency of the information warfare promoted by Kremlin is given by the post-truth culture of the 21 st century, which directly influences those who fall victims to the followers of disinformation. Thus, virtual space is becoming a real battlefield aimed at inoculating alternative realities into the minds of the victims. Russian Maskirovka is taking advantage of an ever-expanding ecosystem in which people confuse false news with the real ones, even more as they are promoted and amplified through social media and the Internet. The cascade effect by which the misinformant becomes disinformant is exactly what the Russian trolls are after to pervert the truth and promote alternative realities.

One of Russia's preferred means, extracted from the hybrid toolbox used in the Ukrainian war, is the energy lever. In general, Western experts and analysts agree that the energy war is a phenomenon of the post-Soviet space, Russia using energy policy with great preference to keep the former Soviet Union countries under its influence. In fact, given the Kremlin's appetite for this exotic instrument, it would be wrong to believe that this strategy cannot be applied to other EU or NATO Member countries. In this respect, based on Ukrainian experience, I believe that one of the hybrid instruments that Kremlin uses to force the regime from Ukraine is the energy component. In fact, in recent years, Russia has used the gas resource intensively as an energy weapon against EU members. As an example, we can recall the reduction in oil supply for the Czech Republic in 2008, in order to sanction Prague because it signed an agreement on the deployment of the US missile defence radar on its territory; in 2007, Russia sanctioned Estonia by suspending oil and coal deliveries for a month, stating that it is a logistical problem; in 2015, Russia reduced oil transit through Lithuanian ports by $20 \%$, without explaining the reason. Taking advantage of huge hydrocarbon resources, Russia is using it as an energy tool to achieve geopolitical goals. In the Russian-Ukrainian war, Russia's particular attention to critical Ukrainian energy infrastructure is due to the fact that a possible sabotage of it does not cause significant economic losses only to Ukraine, but also threatens the energy security of European countries. Thus, the hybrid warfare in Ukraine is becoming global. Taking advantage of the Ukrainian state's total dependence on Russian energy, in all energy sectors, after the annexation of Crimea and the escalation of fights in southeastern Ukraine, Kremlin launched the energy attacks against it, using the energy factor in a three-dimensional format: political, economic and information.

The political dimension - Russia uses energy policy as a tool to achieve its foreign policy objectives. Since 2015, the Russian government has been insistently supporting the termination of the Russian-Ukrainian transit contract, the Russian gas transit route to Europe through Ukraine will be closed as of $2019^{20}$. At the same time, Russia announced the promotion of several possible projects for the delivery of Russian gas to Europe, bypassing the Ukrainian route (North Stream 2, South Stream, Turkish Stream).

Economic dimension - in April 2014, Russia unilaterally established a price of 485 dollars per thousand cubic meters for gas supplied to Ukraine, while European countries bought the gas on average with 360 dollars per thousand cubic meters $^{21}$. Since June of the same year, Russia has stopped gas deliveries to Ukraine ${ }^{22}$. At the same time as the natural gas deliveries were stopped, about $80 \%$ of the coal mines, in the Donbas and Donetsk mining basins, in the area controlled by the Russian separatist forces, were taken out of operation, while the railways and bridges were destroyed. The impossibility of supplying coal from occupied Ukrainian regions has led to an energy crisis on the eve of the 2014/2015 heating season ${ }^{23}$. In order to avoid energy lack and emergency situations, power cuts have been implemented for the people of Ukraine and some energy-consuming enterprises have started to work overnight, the Ukrainian Government seeking coal suppliers worldwide. The lack of coal has become a long-term challenge for Ukraine's energy security, affecting the functioning of Ukraine's entire energy system. After the annexation of Crimea, Moscow gained control of Ukrainian oil facilities located in the administrative region of Crimea. According to the statements of the Ukrainian Ministry of 
Energy and Coal Industry, after the annexation of the peninsula, the costs of energy installations in Crimea, including offshore reserves, were estimated at $\$ 300$ billion $^{24}$. As a result of this aggression, Ukraine has not only lost the energy installations on the territory of Crimea, but also the control over the oil fields of the Black Sea continental area. Out of these natural gas deposits, a volume of 2 billion cubic meters has been appropriated by Russia every year.

The information dimension - Energy has become a Russian propaganda tool through which it creates psychological information pressure on Ukrainian society and the global community in general. Moscow has repeatedly accused Kiev of unauthorized extraction of transit gases destined for European consumers at the beginning of the conflict in Crimea. The purpose of the false accusations was to denigrate Ukraine's image in the eyes of Western partners, being described as an untrustworthy supplier in their eyes and, respectively, to cultivate distrust in Ukrainian authorities. Transformation in the energy market and reform of Ukrainian national energy policy have often been used by pro-Russian organizations as an information opportunity for critical assessment of government action and acceleration of social psychosis ${ }^{25}$.

At the same time as Russia's hybrid instrument in the Ukrainian war was used, the conflict developments have reanimated the issue of limited war. The concept of limited war has an even longer history than that of crisis management, but it has become visible with the emergence of nuclear weapons that have introduced in the equation the zero stake of an armed conflict. The concept is based on the idea that the warriors may opt not to fight at full capacity, so that a conflict does not gain in intensity or extend in space and time. This is different from the acceptance of those natural limits imposed by resources and geography, and also from the circumstances in which a strong state uses only limited forces to deal with opponents with lower capabilities. Complete victories can be achieved against lower opponents with limited effort. In order to be a "limited war", the limits must be accepted by both parties. This is exactly the situation in the Ukrainian war, where the confrontation has turned into an inter-state war with high stakes, in which one of the party is a great nuclear power and the other is under the protective, soft-power-type wing of a military alliance with an impressive nuclear arsenal. The great armies of the parties, bearing in mind the risk of an escalation of the military conflict, have not moved against each other, their capacities being held in reserve and diplomatic communications continued throughout the conflict. It is certain that NATO did not want and did not have the necessary levers to get directly involved in the fight, but had to consider whether and how it could get involved. This involved assessing Russian targets, advising Ukraine on how to react and examining the implications for any conflict that may arise between Russia and a NATO member in the future.

\section{Conclusions}

After the illegal annexation, Crimea has become an important outpost for Kremlin's policy; from this region Russia can undisturbed use its influence in the warm waters of the Black Sea, the Mediterranean and the Middle East. With maritime access to these areas, Russia is maintaining and intensifying the tensions in Libya and Syria, demonstrating its ability to destroy all Western projects related to stabilization, energy security or economic security. All this strategy, which also demonstrates Russia's inability to build something sustainable globally, is intended to impose Russia as a global player that counts in determining the direction of geopolitical challenges between the West and the players from the Middle East and MENA States.

After the invasion of the Crimean Peninsula and the escalation of conflicts in Southeast Ukraine, it has become clear that Russia's policy is focused on preserving its influence and strategic control over the decisions and political directions taken by the States from the former Soviet bloc. Kremlin has adopted several strategies to maintain control over former regions, by attracting States to Eurosiatic alliances and unions (for example, Belarus), by facilitating frozen conflicts in certain separatist regions disconnected from the state of origin (e.g. Ahazia, South Ossetia, Transnistria, Nagorno Karabakh) or in cases deemed to be of extreme necessity, by enclosing and annexing regions of the States of origin (for example, Crimea). All these strategies have a common catalyst: the Russian minority. In countries where there is no significant Russian minority but which has a geostrategic interest to the Russian Federation, it adopts other 
non-conventional or hybrid strategies, usually below the detection limit, using hybrid instruments such as black propaganda, energy, diplomatic, cyber, information policies or corruption of leaders.

The confrontation between Russia and the West, which led to the Russian-Ukrainian conflict, has raised important questions about NATO's credibility as a guarantee of European security. The successful deployment of hybrid instruments in Ukraine demonstrated the complexity of the next generation war led by Russia. Instead of engaging a classic military invasion into Ukraine, which would have led to unprecedented sanctions for the Russian Federation, it adopted an insidious and subversive strategy, which consisted in a mix of ingeniously mixed instruments and tactics that facilitated the achievement of the Kremlin's political goal. So, in annexation of Crimea, Russia deployed special military and paramilitary forces, sustained information campaigns, media propaganda, cyber and electronic aggression, economic, energy or political constraints. The geopolitical problem that the West will have to address is how NATO could react to similar developments, especially if the aggressed state could be a member of the Alliance. Russia's ability to implement hybrid and subversive tactics makes redundant the need to use conventional means of war.

The West's dilemma is whether the hybrid aggression of the Russian Federation against NATO Member States can be anticipated and can trigger a response from the Alliance by removing the threshold of action against it. It is therefore important to study Russia's strategy of using hybrid tactics with the aggression in Georgia or Ukraine as case studies. To understand how different instruments can be used by the Russian Federation to influence the States in its proximity and, in particular, how their combination leads to an effective satisfaction of the aims, it is useful to assess and address the systemic risks and vulnerabilities of States in the disputed areas of Russia and the West in recent years. It is clear that this is not only relevant for the States at the borders of the Russian Federation, globalization and fierce competition for resources and influence, reversing on other States in various alliances, economic and military organizations or unions with the affected States. I believe that although the effects associated with the hybrid tactics carried out by Russia are naturally felt much more acutely in pro-Western countries, but which are not part of the EU or NATO, such as Ukraine, Georgia, Moldavia, Azerbaidjan, the use of similar tactics or elements of such tactics could also be extended against existing members of NATO or the EU.

In order to be able to understand the effects of the Russian-Ukrainian war on the West, as well as to anticipate and counter a possible future evolution of similar phenomena, in countries with geopolitical risks such as Moldavia, but even NATO members such as the Baltic countries, Romania or Bulgaria, it is worth paying attention to the geopolitical consequences of the loss of Crimea and southeastern provinces by Ukraine. For the Russian Federation, the Crimean Peninsula is a convenient basis not only for the Black Sea, but also for launching military operations in the Mediterranean Sea and the Middle East. In fact, the economic potential of the Middle East, and the competition for resources that has caused a problem between the interests of the major world powers such as the United States, China and Russia, has turned it into the most important geostrategic regions on the ground.

The strategic takeover of the peninsula by the Russian Federation led, among other things, to a decrease in Ukrainian military capacity in the Black Sea, with Russia taking over control of maritime trade routes to the Bosporus. The access to Transnistria with subordinate Crimea would allow Russia to become stronger in the Black Sea basin, finally, bringing Turkey back from the US influence and create the conditions for solving alternative sources and supply routes to Europe by strengthening its position in the Caspian region in the future.

The annexation of Crimea has automatically changed the poles of power in territorial waters and waters belonging to Russia's exclusive economic zone, which in the Azov Sea means the blockade of Ukrainian ports by Russia. The annexation has led to the restriction of Ukraine's access to important trade routes, to Crimea ports, access to oil and gas resources from the Black Sea continental area under the control of Russian trainers. Ukraine's exploitation of these deposits would have guaranteed energy independence for a long time, which would have diminished Russia's ability to control Ukrainian politics. From a military point 
of view, Russia's takeover of Crimea has allowed Kremlin to increase Russian military potential in this area, which is at the border with the European Union and NATO, creating military pressure on Ukraine, the Middle East and Eastern Europe.

From geostrategic point of view, Russia's presence in Crimea, control of Transnistria, fueling separatist emotions in eastern Ukraine and strengthening the military alliance with Belarus, enclaves Ukraine by condemning it to a forced change of political direction. Ukraine's fundamental problem is that it does not belong to any military bloc, this unfavorable circumstance causing it to be able to rely only on its own forces in the event of a threat. The red line represented by Crimea Transnistria - Belarus - Kaliningrad strengthens the Russian Federation's position toward NATO, allowing Russia to launch a military offensive against Alliance member states, from several directions at the same time.

The success of the annexation of Crimea has brought a propagandistic victory to Western supporters who sympathize with Russia's politics. Understood as lumen ex oriente, it is perceived as a defender of traditional Christian values, of the family and of a healthy moral marriage between a man and a woman, in front of the modern views of the man promoted by the institutions of the European Union.

\section{NOTES:}

1 Wojciech Łysek, "Crimeea in great powers foreign policy: bordeland-conflict-destabilization", Polskie Towarzystwo Geopolityczne, 11/2015, pp. 37-53, https://www.ceeol.com/ search/viewpdf?id=497802, accessed on.21.05.2021.

2 Stepan Rudnicki (1877-1937), member of the Ukrainian Academy of Sciences, German historian, geographer and philologist.

3 1568-1570, 1676-1681, 1686-1700, 1710-1711, 1735$1739,1768-1774,1787-1792,1806-1812,1828-1829,1853-$ 1856, 1877-1878, 1914-1918.

4 Michal Siudak, "Geopolityczne Wizje Krymu I Ukrainy", Przeglad Geopolityczny 18, p. 88, https://www. ceeol.com/search/article-detail $\mathrm{id}=494566$, accessed on 05.04.2021,

5 Halford Mackinder (1861-1947).

6 https://www.britannica.com/biography/HalfordMackinder, accessed on 05.04.2021.

7 L. Diaconescu, "Island of the World - Moving the World Strategic Center from Heartland to the Indian Ocean", Romanian Journal of Political Geography, 22 (1), 22 (1), p. 2.

8 Right Honourable Sir Halford J. Mackinder, Democratic Ideals And Reality - A Study in the Politics of Reconstruction, NDU Press, Defence Classic Edition, 1942, p. XVIII, https:// www.files.ethz.ch/isn/139619/1942_democratic_ideals reality.pdf, accessed on 05.04.2021.

$9 \mathrm{https}: / /$ www.britannica.com/place/heartland, accessed on 05.04.2021.

10 Zbigniew K. Brzezinski,.1928 (reed 1997), The grand chessboard: American primacy and its geostrategic imperatives / Zbigniew Brzezinski.- ${ }^{\text {st }}$ ed., p. 46, https:// www.cia.gov/library/abbottabad-compound/36/36669B789E 857AC4F3445EA646BFFE1_Zbigniew_Brzezinski_-_The Grand_ChessBoard.doc.pdf, accessed on 05.04.2021.

11 https://encyclopedia.1914-1918-online.net/article/ concept_of_mitteleuropa, accessed on 05.04.2021.

12 Russian philosopher, founder of the current called neo-Eurasianism, political scientist, sociologist, professor at Lomonosov University in Moscow, leader of the International Eurasian Movement.

13 http://www.youtube.com/watch?v=1PPuRIC9fok, http://www.youtube.com/watch?v=FBrQDCpTtFs, http:// www.youtube.com $/$ watch $/ \mathrm{v}=01 \mathrm{~W} 6 \mathrm{v} \_0 \mathrm{wfc}$, accessed on 06.04.2021.

14 Aleksandr Dughin, Multipolar world theory, People's University of Chișinău, 2014, p. 191.

15 Oleg Kondratenko, Ukraine as a Geopolitical Priority of the Russian Federation, Universitatea Naţională de Aviaţie, Kiev, Ucraina, 16/2016, pp. 101-116, https://www.ceeol.com/ search/article-detail?id=623548, accessed on 21.05.2021.

16 Iulian Chifu, Oazu Nantoi, Information warfare. Aggression type-model, I. C. Brătianu Institute of Political Science and International Relations Publishing House of the Romanian Academy, Bucharest, 2016, pp. 5-7.

17 Mihai-Cristian Stancu, „The information war. Case study: The role of «Russia Today» to cover the mission carried out by the Russian Federation in Eastern Ukraine, between May 2014 and February 2015", "Carol I" National Defence University No. 4/2019, p. 50.

$18 \mathrm{https}: / /$ globalnews.ca/news/4260938/russia-strategymaskirovka-military-politics-putin/, accessed on 21.05.2021.

$19 \mathrm{https}$ ://warisboring.com/maskirovka-is-russiansecret-war/, accessed on 21.05.2021.

20 https://www.digi24.ro/stiri/externe/rusia/vladimirputin-ameninta-din-nou-europa-cu-arma-energetica-existariscul-ca-tranzitul-gazului-prin-ucraina-sa-se-intrerupa1217137, accessed on 08.04.2021.

$21 \mathrm{https}$ //www.bursa.ro/rusia-a-crescut-pretul-gazuluipentru-ucraina-la-485-dolari-pe-1000-metri-cubi-60404323, accessed on 08.04.2021.

$22 \mathrm{https} / / / \mathrm{www} . e c o n o m i c a . n e t / r u s i a-a m e n i n t a-d i n-n o u-$ ucraina-cu-sistarea-furnizarii-gazelor_93764.html, accessed on 08.04.2021.

$23 \mathrm{https} / /$ www.economica.net/ucraina-trebuie-sa-cum pere-carbune-de-la-rusia-pentru-a-trece-cu-bine-iarna-minis trul-energiei_91326.html, accessed on 08.04.2021.

$24 \mathrm{https}$ ://worldview.stratfor.com/article/energy-instru ments-hybrid-warfare, accessed on 08.04.2021.

25 Recent reports about the Italian company Eni's intention to drill shale gas exploration wells in Ukraine have been accompanied by an explosion of critical publications on environmental issues, comparing shale gas production to the Chernobyl disaster. The announcement of the supply of fuel for Ukrainian nuclear power plants by the American 
Westinghouse Electric Company also provoked critical comments in the expert environment and the promise of a "second Chernobyl".

\section{REFERENCES}

Brzezinski Zbigniew K, The grand chessboard: American primacy and its geostrategic imperatives (reed. 1997) Basic Books, A Member of the Perseus Books Group, 1st ed., 1928.

Chifu Iulian, Oazu Nantoi, Information war. Typing the model of aggression, Publishing House of the Institute of Political Science and International Relations I.C. Brătianu of the Romanian Academy, Bucharest, 2016.

Diaconescu L., "Island of the World - Moving the World Strategic Center from Heartland to the Indian Ocean", Romanian Journal of Political Geography, 22 (1), 2020.

Dughin Aleksandr, Theory of the multipolar world, People's University, Chișinău, 2014.

Kaplan Robert, Revenge of Geography, Litera Publishing House, Bucharest, 2019.

Kondratenko Oleg, Ukraine as a Geopolitical Priority of the Russian Federation, National Aviation University, Kiev, Ukraine, 16/2016.

Łysek Wojciech, "Crimea in great powers foreign policy: bordeland-conflict-destabilization", Polskie Towarzystwo Geopolityczne, 11/2015.

Mackinder J. Halford, Democratic Ideals And Reality - A Study in the Politics of Reconstruction, NDU Press Defence Classic Edition, 1942.
Maior George, Sergei Konoplyov, Strategic knowledge in the extended area of the Black Sea, RAO Publishing House, Bucharest, 2011.

Siudak Michał, "Geopolityczne Wizje Krymu I Ukrainy", Przeglad Geopolityczny 18.

Stancu Mihai-Cristian, ,The information war. Case study: The role of «Russia Today» to cover the mission carried out by the Russian Federation in Eastern Ukraine, between May 2014 and February 2015", "Carol I" National Defence University No. 4/2019.

https://www.britannica.com/biography/Halfo rd-Mackinder

https://encyclopedia.1914-1918-online.net/ article/concept_of_mitteleuropa

$\mathrm{http} / / / \mathrm{www}$. youtube.com/watch?v=1PPuRlC9fok

http://www.youtube.com/watch?v=FBrQDCpTtFs

http://www.toutube.com/watch/v=0IW6v 0wfc

https://globalnews.ca/news/4260938/russiastrategy-maskirovka-military-politics-putin/

https://warisboring.com/maskirovka-is-russi an-secret-war/

https://www.digi24.ro/stiri/externe/rusia/ vladimir-putin-ameninta-din-nou-europa-cu-armaenergetica-exista-riscul-ca-tranzitul-gazului-prinucraina-sa-se-intrerupa-1217137

https://www.bursa.ro/rusia-a-crescut-pretulgazului-pentru-ucraina-la-485-dolari-pe-1000metri-cubi-60404323

https://www.economica.net/rusia-amenintadin-nou-ucraina-cu-sistarea-furnizarii-gazelor 93764.html

https://worldview.stratfor.com/article/energyinstruments-hybrid-warfare 